\title{
XII. Account of a violet dyeproduced from the leaves of succotrine aloes, which resists the action of oxygen, acids and alkalis
}

\section{Mr. Fabbroni}

To cite this article: Mr. Fabbroni (1798) XII. Account of a violet dyeproduced from the leaves of succotrine aloes, which resists the action of oxygen, acids and alkalis, Philosophical Magazine Series 1, 1:1, 56-58, DOI: $10.1080 / 14786447808676793$

To link to this article: http://dx.doi.org/10.1080/14786447808676793

曲 Published online: 04 Mar 2010.

Submit your article to this journal $\pi$

Џll Article views: 3

Q View related articles $\sqsubset$ 


\section{$\left[\begin{array}{ll}5^{6} & ]\end{array}\right.$}

XII. Account of a Violet Dyeproduced from the Leaves of Succotrine Aloes, wizich refijls tbe Action of Oxygen, Acids and Alkalis. By Mr. FABBroNI. From the Annales de Chimie, Vol. XYV.

To increafe the number of dyeing fubftances, and to be able to vary the tone and thades of the different known colours, is an object of no fmall utility. Several manufactures, as is well known, have been indebted for their reputation and credit to the poffeffion of a particular dye.

Without fpeaking of the Tyrian purple, who is ignorant how much value the modern fcarlet has given to the Dutch cluths and to thofe of the Gobelins? Who does not know that the beautiful black of Florence, which has never yet been initated, has raifed the Florentine ftuffs all over Europe to a price to which that of no other country ever attained?

Scarlet and black belong to that clafs of colours called noble or fived, becaufe they are not fufceptible of being ftained, and becaufe they expericnce no alteration either fron the air or from light. The beautiful red colour alfo given to filk by fafflower is reckoned among the noble colours, though it does not withftand the influence of thefe two agents, which foon defiroy it or render it pale.

All other red dyes for filk, in order to be durable, mult be compofed, in part, of cochineal, which is a colouring fubftance exceedingly conftant.

Archile and all the other lichens produce a very beautiful violet; but the fun alters this colour and makes it turn blue.

I am of opinion, therefore, that if means could be difcovered to compofe, without cochineal, colours graduated frum the moft delicate to the darkeft violet purple, which might be proof againt the action of acids and of the air, infinie advantages would thence refult to the manufacturers of cloth and to the public. 
It was in hopes of difcovering fuch a colour that I directed my refearches towards a fubftance which hitherto has not been rankcd among thofe called colouring fubftances.

I was perfuaded that the matter of the brilliant colours prefented to us in thofe fruits, flowers, and plants, which have undergone a fpontancous alteration, pre-exifts in the mafs of the fluids that circulate in thofe organs, where it is difperfed or concealed; and that to be able to turn it to advantage, nothing would be wanting but a method to feparate it, and to modify it in a proper manner.

The cochineal infect, which lives on the nopal (cactus coccenilifer), can extract with its probofcis the red juice, or juice fufceptible of becoming red, of that plant; which afterwards communicates its colour to the infect, and which, in ny opinion, is the fame as that exhibited to us naked in the ripe fruit of the fame plant.

The beautiful fcarlet colour affumed by the dead leaves of fome fpecies of ftrawberry blite (blitum) is not perhaps brought forwards but in confequence of the decompofition of the dead leaf. Would it be impolfible then for art to feparate this colour, aud to modify it in the like manner?

Having obferved that the fucculent leaves of the aloe fuccotrina inguflifolia, as they dried on the plants, affumed an agreeable violet colour, I tried to feparate the colouring mattcr, or principles of that fine colour, from the living leaves.

I found by experiments, that acids as well as alkalis fpeedily gave to this almoft colourlefs juice a red colour, and formed a fucceffive precipitation of colouring molecula which had the fame colour.

Oxygen gas produced the like effeet; and it is highly pleafing to fee how the juice of aloes, merely by being expofed to the air, with or without the contact of the light, fucceffively reddens, beginning at the parts more immediately in contact, and is gradually converted into a very dark and lively violet purple. 
This juice then produces a fuperb tranfparent colour without body, highly proper for works in miniature, and which when diffolved in water may ferve alfo, either cold or warm, for dyeing filk from the lighteft to the darkeft thade.

Silk, even without a mordant, ftrikes and becomes impregnated with this dye. It is equally attracted by fulphurized filk, though the latter is fo little difpofed to affume any colour whatever.

The aloe, indeed, is not a plant indigenous in our climates; but this is an inconvenience which it has in common with almoft all fubftances ufed for dyeing, and even with a great number of thofe which ferve us as food. The juice might be procured from Socotora itfelf, not fuch as it is found in commerce infpiffated by fire, but dried in the air, or prepared by an acid.

Befides, as this plant grows without any difficulty in our botanical gardens, we may hope to multiply it enough by cultivation, particularly in the fouthern parts of Italy, in order to extract from it the juice ourfelves.

The value of this new colour may be readily difcovered, when we obferve that, by its property of not being altered by acids or alkalis, it poffeffes the uncommon quality of nor being fufceptible of becoming fpotted.

When we confider alfo that the oxygen, which difcolours our cloths and filks fo as to render them white, is, as one may fay, the principle which develops the colour of the aloe; it ought to be inferred, that the air cannot alter a quality which it communicates itfelf; and we may therefore conclude, that we have difcovered in the aloe one of the moft durable colours known in nature. 